\title{
Correction to: Patient and Surgeon Expectations Prior to Anterior Cruciate Ligament Reconstruction
}

Mahmoud Michael Khair, MD • Hassan Ghomrawi, PhD, MPH • Sean Wilson, MD • Robert G. Marx, MD, MSc, FRCSC

Correction to: HSSJ (2018) 14(3):282-285

https://doi.org/10.1007/s11420-018-9623-7

The degree and affiliation of author Hassan Ghomrawi were listed incorrectly in the original article. They are corrected here.

Open Access This article is distributed under the terms of the Creative Commons Attribution 4.0 International License (http:// creativecommons.org/licenses/by/4.0/), which permits unrestricted use, distribution, and reproduction in any medium, provided you give appropriate credit to the original author(s) and the source, provide a link to the Creative Commons license, and indicate if changes were made.

The online version of the original article can be found at https://doi.org/ 10.1007/s11420-018-9623-7

M. M. Khair, MD $\cdot$ S. Wilson, MD •

R. G. Marx, MD, MSc, FRCSC ( $₫)$

Hospital for Special Surgery,

535 East 70th Street,

New York, NY 10021, USA

e-mail: marxr@hss.edu

H. Ghomrawi, PhD, MPH

Feinberg School of Medicine, Northwestern University,

Chicago, IL, USA 